\title{
Ingestive behavior and movement patterns of steers grazing sorghum and supplemented with concentrate
}

\section{Comportamento ingestivo e padrões de deslocamento de novilhos suplementados em pastagem de sorgo forrageiro}

\author{
Viviane Santos da Silva ${ }^{1 *}$; Ivan Luiz Brondani²; Dari Celestino Alves Filho²; \\ Perla Cordeiro de Paula Colvero ${ }^{1}$; Amanda Farias de Moura ${ }^{3}$; Camille Carijó \\ Domingues $^{3}$; Mauren Burin da Silva ${ }^{3}$; Marcelo Ascoli da Silva ${ }^{3}$
}

\section{Highlights:}

Grazing time decreased throughout the experimental period.

Grazing time varied in the morning using a higher level of supplementation (1.2\% of body weight).

The biting rate of steers varied during the growth stages of sorghum.

\begin{abstract}
The present study was developed at the Beef Cattle Laboratory of the Federal University of Santa Maria and evaluated the effect of three levels of concentrate supplementation (S 0.8, S 1.0, and S 1.2, corresponding to $0.8 \%, 1.0 \%$, and $1.2 \%$ of bodyweight, respectively) on the ingestive behavior and movement patterns of 24 steers grazing on sorghum. The experiments were performed using a completely randomized block design in a $3 \times 3$ factorial arrangement (three levels of supplementation - three experimental periods), and the grazing time was evaluated using a $3 \times 24$ factorial arrangement (three levels of supplementation - 24 hours of observation). The steers fed S 0.8 presented longer $(\mathrm{P}=0.009)$ grazing time in the morning $\left(241 \mathrm{~min} \mathrm{day}^{-1}\right)$ compared to animals fed S 1.2(172 min day $\left.{ }^{-1}\right)$. The number of bites per feeding station was higher (4.05) during the second experimental period, and the number of bites $\mathrm{min}^{-1}$ increased from 25.4 to 31.4 from the first to the second experimental period. The changes in sward structure during the growth stages of sorghum affected the number of bites per feeding station and the number of bites per minute.
\end{abstract}

Key words: Biting rate. Concentrate supplementation. Grazing time. Idling time. Sorghum bicolor.

\section{Resumo}

O presente estudo foi desenvolvido no Laboratório de Bovinocultura de Corte da Universidade Federal de Santa Maria e teve como objetivo avaliar a influência de três níveis de suplementação energética (S 0,$8 ; \mathrm{S} 1,0$ ou S $1,2 \%$ do peso corporal) sobre o comportamento ingestivo e os padrões de deslocamento de 24 novilhos mantidos em pastagem com sorgo forrageiro. Foi utilizado o delineamento experimental inteiramente casualizado em fatorial $3 \times 3$ (três níveis de suplementação x três períodos de avaliação

1 Zootecnistas, Dr ${ }^{\text {as }}$ em Produção Animal, Universidade Federal de Santa Maria, UFSM, Santa Maria, RS, Brasil. E-mail: stsvivi@ gmail.com; perla.zoot@gmail.com

2 Profs. Drs., Departamento de Zootecnia, UFSM, Santa Maria, RS, Brasil. E-mail: ivanbrondani@gmail.com; darialvesfilho@ hotmail.com

3 Zootecnistas, Mestres em Produção Animal, Discentes de Pós-Graduação, Departamento de Zootecnia, UFSM, Santa Maria, RS, Brasil.E-mail: af.moura@hotmail.com; camidomingues1@gmail.com; maurenburin@hotmail.com; maszootec@live.com

* Author for correspondence

Received: Apr. 29, 2020 - Approved: Aug. 02, 2020 
da pastagem) e para análise dos dados da frequência de pastejo um fatorial 3 x 24 (três níveis de suplementação e 24 horas de observação). Os novilhos do tratamento $\mathrm{S} 0,8$ apresentaram maior $(\mathrm{P}=0,009)$ tempo de pastejo durante o turno da manhã (241 min. dia $\left.{ }^{-1}\right)$ comparado aos animais do tratamento $\mathrm{S}$ 1,2 , que despenderam 172 min.dia $^{-1}$ nesta atividade. O maior número de bocados estação ${ }^{-1}(4,05)$ foi registrado durante o segundo período experimental, enquanto a taxa de bocados min. ${ }^{-1}$ aumentou de 25,4 (primeiro período) para 31,4 (segundo período). $\mathrm{O}$ fornecimento do equivalente a $1,2 \%$ do peso corporal em suplementação energética promove a diminuição do tempo de pastejo durante o turno da manhã comparado a oferta de $0,8 \%$. A variação estrutural da pastagem de sorgo forrageiro ao longo do seu ciclo produtivo promove variação no número de bocados por estação alimentar e taxa de bocados min..$^{-1}$ de novilhos suplementados.

Palavras-chave: Sorghum bicolor. Suplementação energética. Taxa de bocado. Tempo de pastejo. Tempo de ócio.

\section{Introduction}

The use of tropical forage crops in grazing systems is common in the southern region of Brazil to improve livestock production. Forage sorghum (Sorghum bicolor L. Moench) is highly adapted to different environments and is productive under unfavorable conditions. In addition, this forage species constitutes a high-quality food source for cattle (Neumann et al., 2010). However, the amount of sorghum in the sward can limit short-term forage intake and productivity (Gregorini et al., 2011; Mezzalira et al., 2014).

Cattle spend most of the day grazing. Therefore, the feeding period should be adequate, and actions should be implemented to maximize the rate of forage intake and decrease the time necessary for animals to reach the daily nutritional requirement (Carvalho, 2013). Feed supplementation for ruminants allows increasing animal performance and the carrying capacity of the pasture to reduce the age at slaughter or age at first calving (Reis, Ruggieri, Oliveira, Azenha, \& Casagrande, 2012). However, supplements may cause metabolic changes and undesirable effects such as reduced feed intake or increased preference for the concentrate (Mobiglia, Camilo, \& Fernandes, 2013).

Therefore, understanding the relationship between cattle production and the environment by evaluating the temporal distribution of activities related to grazing, rumination, idling, and movement can help improve feed management systems
(Chilibroste, Gibb, Soca, \& Mattiauda, 2015). The objective of this study is to evaluate the ingestive behavior and movement rate of steers grazing sorghum and supplemented with concentrate during the finishing phase.

\section{Materials and Methods}

This study was approved by the Ethics Committee on the Use of Animals (Comitê de Ética de Utilização de Animais-CEUA) (Opinion No. 146/2014) from the Federal University of Santa Maria (Universidade Federal de Santa MariaUFSM), Santa Maria, Rio Grande do Sul, Brazil, and was conducted at the Beef Cattle Laboratory at UFSM (altitude, 95 m; latitude, 29²43' S, longitude, $\left.53^{\circ} 42^{\prime} \mathrm{W}\right)$.

Twenty-four steers (Charolais - Nellore) with a mean age of 16 months and initial body weight (BW) of $334.58 \pm 5.23 \mathrm{~kg}$ were used. The animals grazed sorghum (Sorghum bicolor) and were supplemented with a concentrate containing white oat grain $(82.5 \%)$, ground corn grain $(15 \%)$, and calcareous limestone $(2.5 \%)$. The animals had free access to water, shade, a mineral mixture $(50 \%$ $\mathrm{NaCl}+50 \% \mathrm{CaHPO}_{4}$ ), and the concentrate, which was provided daily in equal amounts at 11:00 am and 5:00 pm.

$\mathrm{BW}$, ingestive behavior, movement rate, and sward characteristics were evaluated during three 28-day experimental periods (EP1, February 15 
to March 15; EP2, March 16 to April 5; and EP3, Abril 6 to April 27). The leaf mass of sorghum was estimated in $1 \mathrm{~m}^{2}$ plots using the double sampling method. The steers were maintained under continuous grazing with variable stocking rates. The mean leaf mass during the study period was 601.84 $\mathrm{kg}$ dry matter $(\mathrm{DM}) \mathrm{ha}^{-1}(\mathrm{P}>0.05)$ and varied from $770.69 \mathrm{~kg} \mathrm{DM} \mathrm{ha}^{-1}$ in EP1 to $585.6 \mathrm{~kg} \mathrm{DM} \mathrm{ha}^{-1}$ in EP2 and EP3 $(\mathrm{P}<0.05)$. The weight gain of the steers was not affected by the level of supplementation, and the mean weight gain in EP1, EP2, and EP3 was $1.353,1.107$, and $1.102 \mathrm{~kg} \mathrm{day}^{-1}$, respectively.

Sward height was measured from the ground level until the upper leaves with average inclination (A. P. M. Martini et al., 2019). The sward structure was analyzed in three $0.25 \mathrm{~m}^{2}$ plots per pen and stratified into four strata $(0-25,25-50,50-75$, and $>75 \mathrm{~cm}$ above the soil surface). Leaves, stems + sheaths, and leaf litter were separated manually in each stratum (Stobbs, 1973). Pastures were sampled using a grazing simulation model (Euclides, Macedo, \& Oliveira, 1992), and concentrate samples were collected for bromatological analysis.

The following treatments were used: S-0.8, forage sorghum + low level of supplementation $(0.8 \%$ of $\mathrm{BW}) ; \mathrm{S}-1.0$, sorghum + intermediate level of supplementation (1.0\% of BW); and S-1.2, sorghum + high level of supplementation $(1.2 \%$ of BW). Each treatment contained four plots with a variable number of animals in each plot and two steers in each pen. The experimental area corresponded to 11.7 hectares and was divided into twelve pens, each with approximately 1 hectare. The experimental period was 70 days (February 15 to April 27, 2013).

The ingestive behavior of four steers from each treatment was analyzed for $24 \mathrm{~h}$ by visual inspection at 10-min intervals in each study period, as described previously (Jamieson \& Hodgson, 1979). The activities were classified as grazing, rumination, idleness, and time spent at each feeding station.
Grazing time was the time spent by each animal in selecting and eating forage, including the short periods of time moving to select the diet (Hancock, 1953). The rumination time was determined by the chewing activity, and idling time was the period in which the animal remained at rest (Forbes, 1988).

The time necessary for the animal to perform 20 bites was recorded during the day (three times in the morning and three times in the afternoon), and the number of bites per min was calculated (Hudgson, 1982). The time spent by steers to travel to ten feeding stations was measured twice in the morning and twice in the afternoon. A feeding station was considered the grazing area on which the animals did not move the front legs (Laca, Ungar, Seligman, Ramey \& Demment, 1992), and a step was defined as each movement of the front legs. These data were used to estimate the movement rate (steps per minute) and the number of feeding stations visited daily. The number of bites per feeding station was calculated by dividing the daily number of bites by the daily number of feeding stations. The number of stations visited per minute was calculated by dividing the daily number of stations by the grazing time.

The experiments were performed using a completely randomized block design in a $3 \times 3$ factorial arrangement (three levels of supplementation - three experimental periods), with four repetitions per plot. The grazing time was evaluated using a $3 \times 24$ factorial arrangement (three levels of supplementation - $24 \mathrm{~h}$ ). The data were subjected to analysis of variance, and the average values were compared using the MIXED procedure. Average values were compared using Student's t-test at a level of significance of 5\%. The data were subjected to the Shapiro-Wilk normality test and Pearson's linear correlation test using the CORR procedure. Statistical analysis was performed using SAS software version 8.1. 


\section{Results and Discussion}

The time spent per feeding station and the time spent ruminating, idling, and grazing were evaluated in the three experimental periods. Given that these activities were interdependent, the decrease in the time grazing and ruminating increased the idling time (Figure 1), as previously observed by Rodrigues et al. (2019), wherein there was a negative correlation between grazing time and rumination time $(\mathrm{r}=0.612 ; \mathrm{p}=0.037)$. The decrease in grazing time may be because of sward structure by the decreased or delayed emission of leaves throughout the experimental period (A. P. M. Martini et al., 2019).

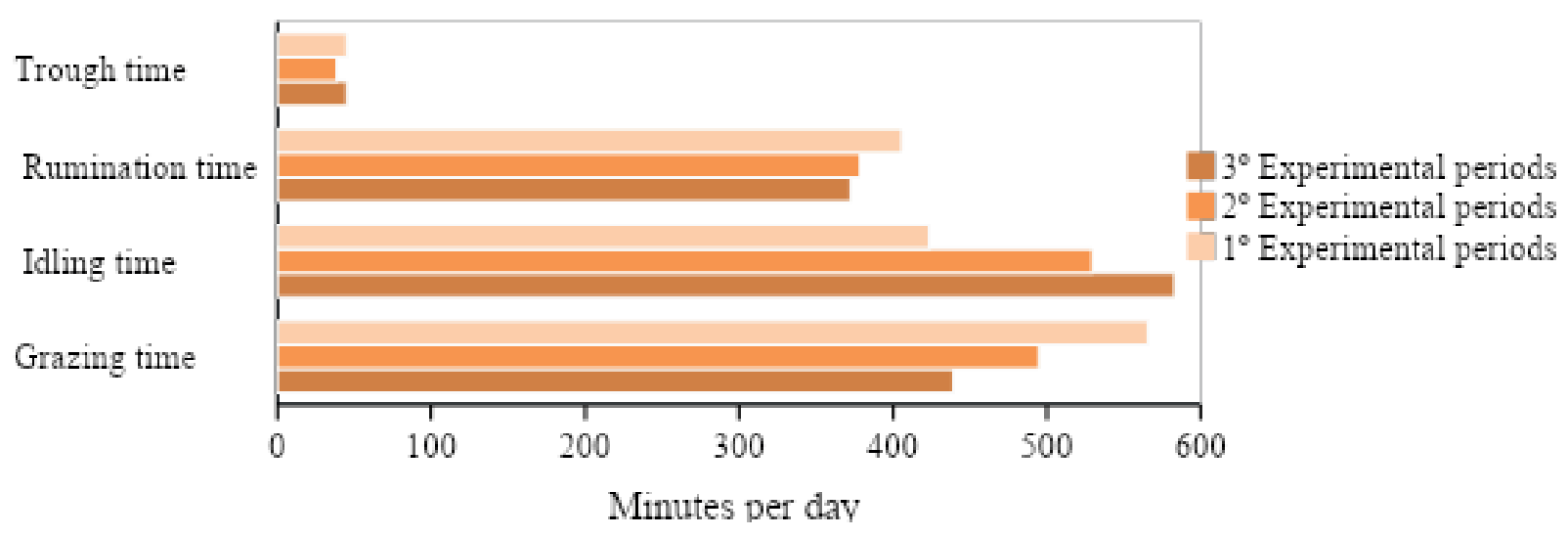

Figure 1. Time spent at each feeding station, and time spent ruminating, idling, and grazing during the experimental periods.

The decrease in grazing time did not affect average daily weight gain because steers consumed less forage but more concentrate (Goes et al., 2010; Sales et al., 2011; Benatti et al., 2012). Similarly, Rodrigues et al. (2019) found that the time spent by heifers grazing sorghum and eating the feed supplement in the trough was 401 and 39 min day $^{-1}$, respectively. The direct correlation between feeding and the ingestion of cell wall justifies the small differences in average forage NDF $\left(643.57 \mathrm{~g} \mathrm{~kg}^{-1}\right.$ of dry matter $[\mathrm{DM}]$ ) and average forage DM between treatments (Table 1) (Carlotto et al., 2010). It is of note that a study found that concentrate intake was negatively correlated with rumination time (Pizzuti et al., 2012; Santana et al., 2012), and the latter was not correlated with weight gain and feed conversion (Santana et al., 2013). The time spent ruminating and at each feeding station (385 and 42 min day $^{-}$ 1 , respectively) were not affected by the level of supplementation or grass growth cycle. 
Table 1

Bromatological analysis of grazed samples and concentrate, and weather conditions on the days of analysis of ingestive behavior

\begin{tabular}{lccccc}
\hline \multirow{2}{*}{$\begin{array}{c}\text { Content } \\
\left(\mathrm{g} \mathrm{kg}^{-1} \mathrm{DM}\right)\end{array}$} & $\begin{array}{c}\text { First period } \\
\text { March of 1998 } \\
\text { to May of 2004 }\end{array}$ & $\begin{array}{c}\text { Grazing simulation } \\
\text { March of 1998 to } \\
\text { May of 2004 }\end{array}$ & $\begin{array}{c}\text { Third period } \\
\text { March of 1998 to } \\
\text { May of 2004 }\end{array}$ & Mean & Concentrate \\
\hline FM/DM* & 274.7 & 322.9 & 339.6 & 312.4 & 847.7 \\
$\mathrm{OM}$ & 933.2 & 910.1 & 902.6 & 915.3 & 952.5 \\
$\mathrm{CP}$ & 168.54 & 188.57 & 163.79 & 173.63 & 128.13 \\
$\mathrm{NDF}$ & 704.82 & 548.12 & 677.75 & 643.57 & 83.02 \\
$\mathrm{ADF}$ & 366.77 & 331.37 & 359.91 & 352.68 & 298.02 \\
$\mathrm{EE}$ & 20.11 & 33.55 & 19.48 & 24.38 & 24.00 \\
TDN & 524.07 & 509.97 & 475.06 & 503.03 & 725.86 \\
\hline Rainfall, mm & 216.4 & 122 & 87.8 & - & - \\
Average temperature $\left({ }^{\circ} \mathrm{C}\right)$ & 22.51 & 20.62 & 18.93 & - & - \\
\hline
\end{tabular}

${ }^{*} \mathrm{~g} \mathrm{~kg}^{-1}$ fresh matter (grass) or dry material (concentrate); OM, organic matter; CP, crude protein; NDFap, neutral detergent fiber corrected for ash and protein; ADF, acid detergent fiber; EE, ether extract; TDN, total digestible nutrients.

Weather data were obtained from the Instituto Nacional de Meteorologia (2013).

The analysis of variance of data on grazing time in the morning showed that there was no interaction between treatment and time of day (Figure 2). Previous studies have shown that the chemical composition of forage varies throughout the day due to the higher rate of photosynthesis and water loss through transpiration in the afternoon and at dusk, increasing nutrient concentration and forage quality during this period, affecting forage selectivity and grazing time (Gregorini, 2012; Sichonany et al., 2015).

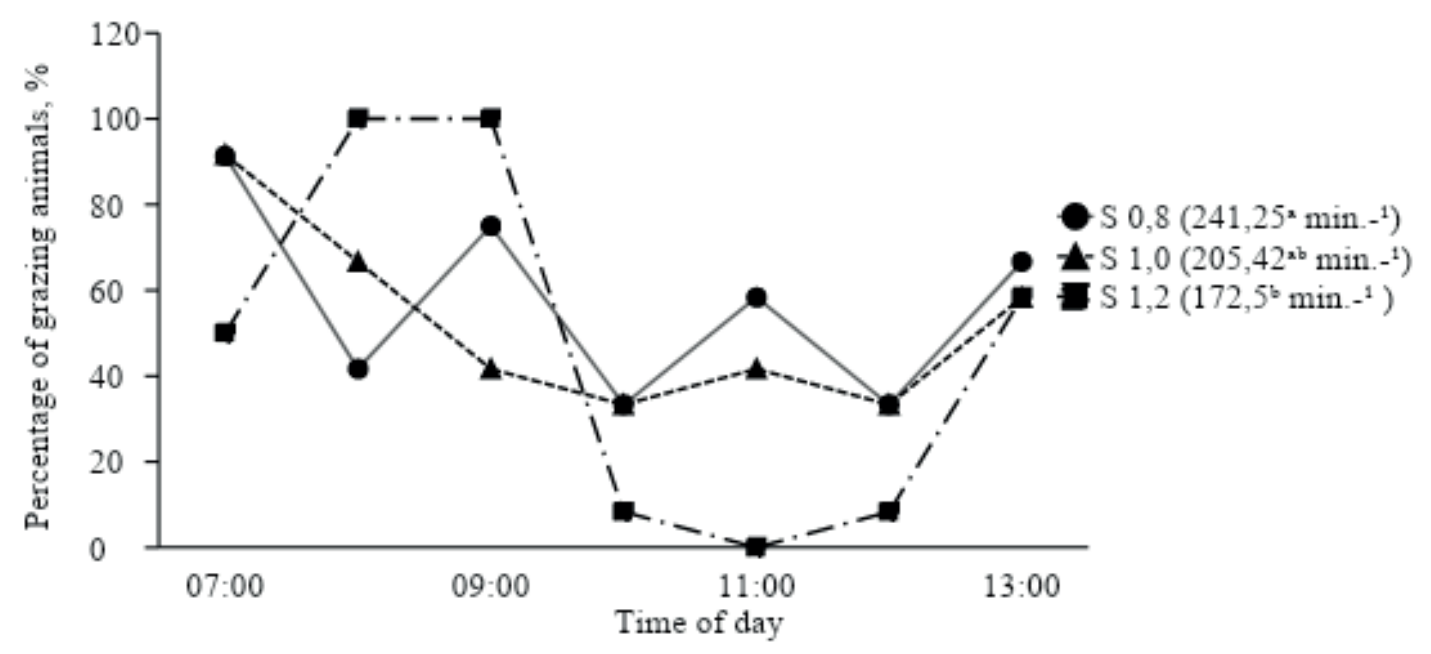

Figure 2. Percentage of steers grazing sorghum according to the level of concentrate supplementation. 
Supplementation does not significantly increase nutrient intake because the production of shortchain fatty acids such as propionic acid decreases ruminal $\mathrm{pH}$, inhibiting cellulolysis and the rate and magnitude of fiber digestion, and increases insulin secretion, which affects DM intake in ruminants (Mobiglia et al., 2013). This effect can be related to quantitative characteristics (1.2\% of BW) and qualitative characteristics $\left(725,86 \mathrm{~g} \mathrm{~kg}^{-1}\right.$ of TDN DM and $83.02 \mathrm{~g} \mathrm{~kg}^{-1}$ of NDFap) of the concentrate, which might have caused a peak in the ruminal production of volatile fatty acids at 2 to $3 \mathrm{~h}$ after feeding, inhibiting grazing activity at later time points. This effect on the rumen environment is stronger using a higher level of supplementation $(>0.8 \%$ of BW) with an expected decrease in forage intake (Silva et al., 2010; Mobiglia et al., 2013).

Cattle graze more frequently in the early morning and at dusk, and the temporal distribution of this activity depends on factors such as breed type, forage species, and concentrate availability. The times pent grazing on tropical grass species varied from 6.73 to $9.04 \mathrm{~h}^{\text {day }}{ }^{-1}$ (Oliveira et al., 2013; Sichonany et al., 2015). In our study, the average grazing time of steers was $8.32 \mathrm{~h}^{\text {day }}{ }^{-1}$, corroborating the results of Scaglia and Boland (2014).

Supplementation did not significantly affect the movement rate (Table 2), probably because leaf mass remained at $601.84 \mathrm{~kg} \mathrm{DM} \mathrm{ha}^{-1}(\mathrm{P}>0.05)$ between treatments, and this variable was affected by the quantity, quality, and structure of the grass. The number of bites per feeding station and the number of bites per min changed throughout the experimental periods $(\mathrm{P}<0.05)$. In the present study, sward height decreased from $79.77 \mathrm{~cm}(\mathrm{P} 1)$ to 56.96 (P2) and $31.30 \mathrm{~cm}$ (P3), as observed previously (A. P. M. Martini et al., 2019). This result might have affected the rate of leaf development and the movement rate during the grass growth cycle (Table 2).

Table 2

Behavior of steers grazing sorghum according to the level of concentrate supplementation

\begin{tabular}{|c|c|c|c|c|c|c|c|c|c|c|}
\hline \multirow[t]{2}{*}{ Variables } & \multicolumn{3}{|c|}{$\begin{array}{l}\text { Level of concentrate } \\
\text { supplementation } \\
\text { (\% of body weight })\end{array}$} & \multirow[t]{2}{*}{ SE } & \multirow[t]{2}{*}{$\mathrm{P}^{2}$} & \multicolumn{3}{|c|}{ Period } & \multirow[t]{2}{*}{ EE } & \multirow[t]{2}{*}{$\mathrm{P}^{2}$} \\
\hline & 0.8 & 1.0 & 1.2 & & & 1 & 2 & 3 & & \\
\hline Movement rate ${ }^{1}$ & 11.8 & 9.5 & 11 & \pm 0.94 & 0.224 & 10.58 & 11.83 & 9.69 & \pm 0.88 & 0.130 \\
\hline $\begin{array}{l}\text { Number of feeding sta- } \\
\text { tions visited per min }\end{array}$ & 8.12 & 7.35 & 8.12 & \pm 0.80 & 0.263 & 8.7 & 7.74 & 8.34 & \pm 0.65 & 0.387 \\
\hline $\begin{array}{l}\text { Time spent at each } \\
\text { feeding station (s) }\end{array}$ & 7.45 & 8.23 & 7.42 & \pm 0.55 & 0.110 & 6.91 & 7.83 & 7.23 & \pm 0.56 & 0.068 \\
\hline $\begin{array}{l}\text { Number of bites per } \\
\text { feeding station }\end{array}$ & 3.55 & 3.94 & 3.43 & \pm 0.23 & 0.075 & $2.92^{\mathrm{b}}$ & $4.05^{\mathrm{a}}$ & $3.47^{\mathrm{b}}$ & \pm 0.34 & 0.042 \\
\hline $\begin{array}{l}\text { Number of bites per } \\
\text { min }\end{array}$ & 28.88 & 28.96 & 27.8 & \pm 0.76 & 0.359 & $25.38 b$ & $31.35 \mathrm{a}$ & $28.91 \mathrm{ab}$ & \pm 1.57 & 0.025 \\
\hline
\end{tabular}

${ }^{1}$ steps $\min ^{-1} ;{ }^{2} \mathrm{P}>$ value; SE, standard error; P1, February 15 to March 15; P2, March 16 to April 5; P3, April 6 to April 27. Means followed by different letters in each line indicate significant differences using Student's t-test $(\mathrm{P}<0.05)$. 
The sward structure determines leaf and stem height as well as forage availability and accessibility to the animals, and affects feeding selectivity, time spent at each feeding station, and grazing time (Fonseca et al., 2013; P. M. Martini et al., 2017). In situations of limited forage availability, animals maintain the intake rate by visiting more stations daily and decreasing selectivity. Under these conditions, the number of steps between stations is reduced because the bite mass at each station is smaller (Teixeira, Marques, Silva, and Pires, 2010).

Although some studies indicate that supplementation affects the daily number of bites because of the increased nutrient intake via supplementation (Santana et al., 2013; Stivanin et al., 2014), we found no significant differences in this variable between treatments (Table 2). The movement rate (9.28 and 11.3 steps $\left.\mathrm{min}^{-1}\right)$ and the number of stations visited per min (6.99 and 7.33) reported by P. M. Martini et al. (2017) and Rodrigues et al. (2019) in cattle grazing sorghum were like those of our study.

The increased number of bites per min in ruminants reflects limitations in forage intake (Teixeira et al., 2010) and compensates for unfavorable pasture conditions, including lower leaf density, higher stem and leaf litter density, and reduced access to forage (Mezzalira et al., 2014). It has been shown that the time spent by heifers at each feeding station (12.28 $\mathrm{min}$ ) decreased as leaf density decreased (Sichonany et al., 2015). The mean number of bites per station and per min in heifers grazing warm-season grasses was 5.25 and 26.85, respectively (Souza et al., 2011), and the number of bites per min in culled cows grazing millet grass and/or Sudan grass was 36.35 (Pacheco et al., 2013). Moreover, the number of bites per min in supplemented heifers decreased from 50 to 32 from the growth stage to the flowering stage of Papua grass (Urochloa plantaginea L.) (Oliveira et al., 2013).

Our results agree with those of previous studies, wherein the number of stations visited per min was 6.67 and the movement rate was 10.40 steps $\mathrm{min}^{-1}$. The positive correlation between sward structure, number of stations visited per min, and movement rate indicates that the latter two variables dictated the number of bites per station and per min (4.05 and 31.35, respectively) (Table 3).

Linear correlations are useful to determine relationships between characteristics or study variables (Cargnelutti, Lopes, Toebe, Silveira, \& Schwantes, 2011). Idling time was negatively correlated with leaf density in strata $25-50 \mathrm{~cm}, 50-75$ $\mathrm{cm}$, and $>75 \mathrm{~cm}(\mathrm{r}=-0.64, \mathrm{p}=0.0001 ; \mathrm{r}=-0.64, \mathrm{p}=$ $0.0001 ; r=-0.70, p=0.001$, respectively), whereas grazing time was positively correlated with leaf density in these strata $(r=0.64, p=0.0001 ; r=0.59$, $\mathrm{p}=0.0002 ; \mathrm{r}=58, \mathrm{p}=0.002$, respectively) (Table 3). These results reinforce the notion that changes in sward structure affect the ingestive behavior of cattle (Fonseca et al., 2013). Stem density in the stratum $50-75 \mathrm{~cm}$ was positively associated with the number of bites per station and per $\min (\mathrm{r}=0.46, \mathrm{p}=$ $0.005 ; r=0.47, p=0.004)$ and negatively correlated with leaf density $(r=-0.37, p=0.027$; and $r=-0.42$, $\mathrm{p}=0.011)$. This finding is corroborated by the result of the morphogenic analysis of sward carried out by A. P. M. Martini et al. (2019). 


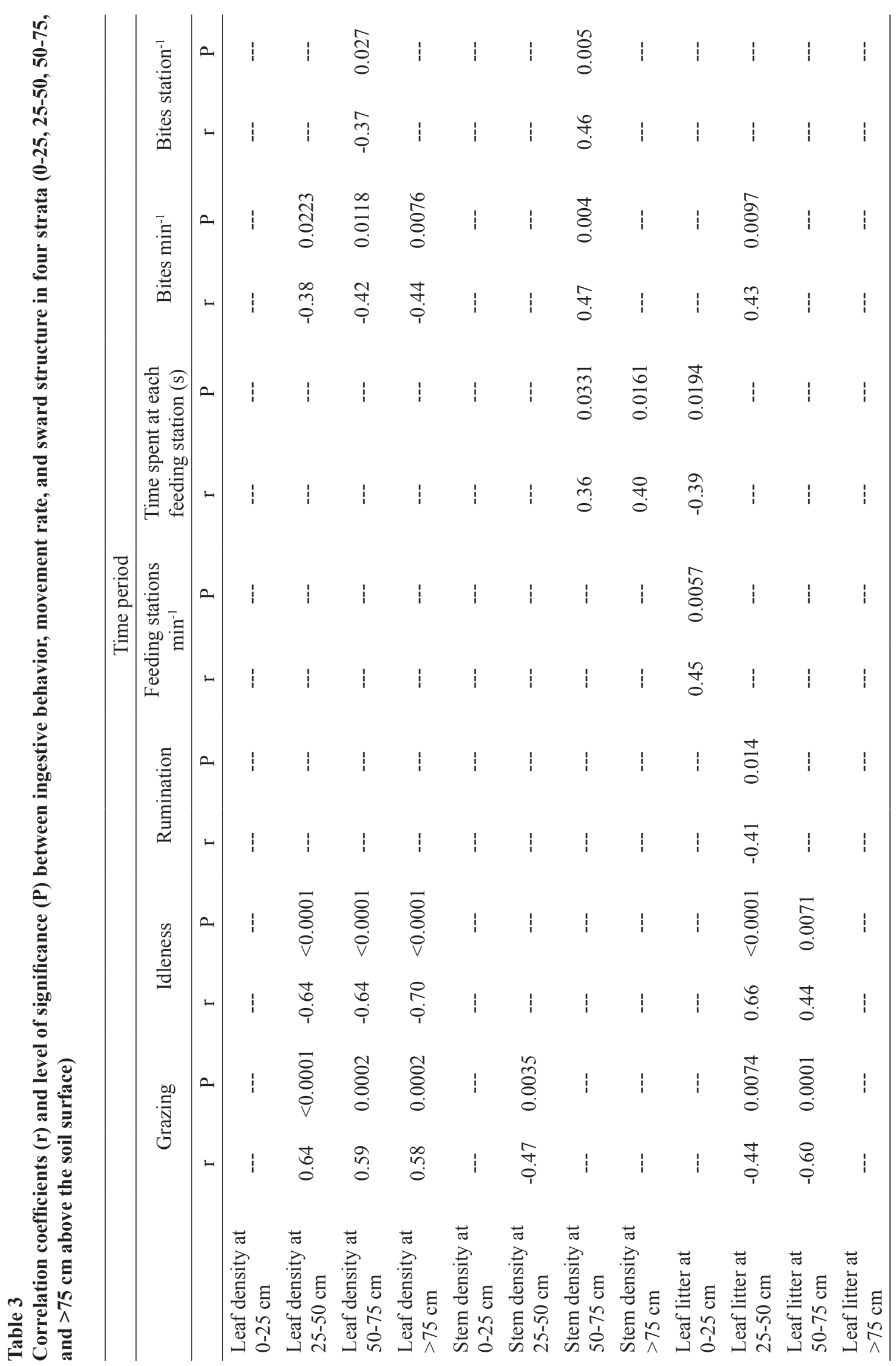




\section{Conclusions}

Higher supplementation levels (1.2\% of BW) for steers fed sorghum reduced the grazing time during the morning period compared to lower supplementation levels $(0.8 \%$ of BW).

The variation in the density of leaves, stems, and leaf litter during the growth cycle of sorghum affected the number of bites per feeding station and per min in steers supplemented with concentrate.

\section{References}

Benatti, J. M. B., Moraes, E. H. B. K., Zervoudakis, J. T., Araújo, C. V., Cabral, L. S., Rufino, J. E., Jr., \& Carvalho, D. M. (2012.) Fornecimento de grão de milheto, inteiro ou triturado, em duas frequências de suplementação para bovinos de corte. Revista Brasileira de Zootecnia, 41(4), 941-950. doi: 10.1590/S1516-35982012000400016

Cargnelutti, A., F., Lopes, S. J., Toebe, M., Silveira, T. R., \& Schwantes, I. A. (2011). Tamanho de amostra para estimação do coeficiente de correlação de Pearson entre caracteres de Crambe abyssinica. Revista Ciência Agronômica, 42(1), 149-158. Recuperado de https://search. proquest.com/openview/ 97c0 $4750 \mathrm{c} 65 \mathrm{f} 7 \mathrm{c} 68 \mathrm{ef} 57299 \mathrm{~b} 5118 \mathrm{~b} 2 \mathrm{a} 1 / 1$ ? pq-origsite $=$ gscholar\&cbl= 2028909

Carlotto, S. B., Medeiros, R. B., Pellegrini, C. B., Garcia, R. P. A., Lisboa, C. A. V., \& Saibro, J. C. (2010). Comportamento ingestivo diurno de vacas primíparas em pastagem nativa dominada por capimannoni-2 com suplementação protéica e mineral em diversas estações climáticas. Revista Brasileira de Zootecnia, 39(3), 454-461. doi: 10.1590/S151635982010000300002

Carvalho, P. C. F. (2013). Harry Stobbs memorial lecture: can grazing behavior support innovations in grassland management? Tropical Grasslands, 1: 137-155. Retrieved from http://www. tropical grasslands.info

Chilibroste, P., Gibb, M. J., Soca, P., \& Mattiauda, D. A. (2015). Behavioural adaptation of grazing dairy cows to changes in feeding managemente: do they follow a predictable pattern? Animal Production Science, 55, 328-338. doi: 10.1071/AN14484

Euclides, V. P. B., Macedo, M. C. M., \& Oliveira, M. P. (1992). Avaliação de diferentes métodos de amostragem sob pastejo. Revista Brasileira de Zootecnia, 21(4), 691-702.

Fonseca, L., Carvalho, P. C. F., Mezzalira, J. C., Bremm, C., Galli, J. R., \& Gregorini, P. (2013). Effect of sward surface height and level of herbage depletion on bite features of cattle grazing Sorghum bicolor swards. Journal of Animal Science, 91, 1-9. doi: $10.2527 /$ jas2013-5602

Forbes, T. D. A. (1988). Researching the plant-animal interface: The investigation of ingestive behavior in grazing animal. Journal of Animal Science, 66(9), 2369-2379. doi: 10.2134/jas19 88.6692369x

Goes, R. H. T. B., Mancio, A. B., Lana, R. P., Cecon, P. R., Alves, D. D., Freitas, T. B., \& Brabes, K. C. S. (2010). Suplementação proteica e energética para novilhos em recria, durante o período da seca. Revista Brasileira de Saúde e Produção Animal, 11(4), 1081-1094. Recuperado de http://www.rbspa. ufba.br/index.php/rbspa/article/viewFile/1839/1033

Gregorini, P. (2012). Diurnal grazing pattern: its physiological basis and strategic management. Animal Production Science, 52, 416-430. doi: 10.1071/AN11250

Gregorini, P., Gunter, S. A., Bowman, M. T., Caldwell, J. D., Masino, C. A., Coblentz, W. K., \& Beck, P. A. (2011). Effect of herbage depletion on short-term foraging dynamics and diet quality of steers grazing wheat pastures. Journal Animal Science, 89, 38243830. doi: $10.2527 /$ jas.2010-3725

Hancock, J. (1953). Grazing behaviour of cattle. Animal Breeding Abstract, 21(1), 1-13.

Hudgson, J. (1982). Ingestive behavior. In J. D. Leaver (Ed.), Herbage intake and handbook. Hurley: British Grassland Society.

Instituto Nacional de Meteorologia (INMET), 2013. Disponível em: https://portal.inmet.gov.br/ dadoshistoricos

Jamieson, W. S., \& Hodgson, J. (1979). The effect of variation in sward characteristics upon the ingestive behavior and herbage intake of calves and lambs under continuous stocking management. Grass and Forage Science, 34, 273-281. Retrieved from http:// www.readcube. com/articles/10.1111\%2Fj.1365

Laca, E. A., Ungar, E. D., Seligman, N., Ramey, M. R., \& Demment, M. W. (1992). An integrated methodology for studying short-term grazing behaviour of cattle. Grass and Forage and Science, 47(1), 81-90. doi: 10.1111/j.1365-2494.1992.tb02250.x 
Martini, A. P. M., Brondani, I. L., Silva, V. S., Alves, D. C., F ${ }^{\circ}$, Martini, P. M., \& Argenta, F. M. (2019). Características morfogênicas e estruturais do sorgo forrageiro submetido a lotação contínua com novilhos de corte suplementados. Ciência Animal Brasileira, 20, 1-11, e-45172. doi: 10.1590/1089$6891 \mathrm{v} 20 \mathrm{e}-45172$

Martini, P. M., Brondani, I. L., Alves, D. C., Fo ., Viana, A. F. P., Adams, S. M., Klein, J. L.,... Cattelam, J. (2017). Comportamento ingestivo de bovinos jovens mantidos em pasto de sorgo ou milheto. Boletim de Indústria Animal, 74(4), 308-3184. doi: 10.17523/ bia.v74n4p308

Mezzalira, J. C., Carvalho, P. C. F., Fonseca, L., Bremm, C., Cangiano, C., Gonda, H. L., \& Laca, E. A. (2014). Behavioural mechanisms of intake rate by heifers grazing swards of contrasting structures. Animal Behaviour Science, 153, 1-9. doi: 10.1016/j. applanim.2013.12.014

Mobiglia,A. M., Camilo, F. R., \& Fernandes, J. J. R. (2013). Comportamento ingestivo e alguns reguladores de consumo em bovinos de corte. PUBVET, 7(17). Recuperado de http://www. pubvet.com.br/uploads/ a2de7345ef962b808909f85ab82e14c4.pdf

Neumann, M., Restle, J., Souza, A. N. M., Pellegrini, L. G., Zanette, P. M., Normberg, J. L., \& Sandini, I. E. (2010). Desempenho vegetativo e qualitativo do sorgo forrageiro (Sorghum bicolor X Sorghum sudanense) em manejo de cortes. Revista Brasileira de Milho e Sorgo, 9(3), 298-313. doi: 10.18512/19806477/rbms.v9n3p298-313

Oliveira, R. A., Neto, Silva, J. H. S., Rocha, M. G., Pötter, L., Sichonany, M. J. O., Biscaíno, L. L.,... Difante, M. V. B. (2013). Ingestive behavior, performance and forage intake by beef heifers on tropical pasture systems. Revista Brasileira de Zootecnia, 42(8), 549-558. doi: 10. 1590/S1516-35982013000800003

Pacheco, R. F., Alves, D. C., F., Brondani, I. L., Restle, J., Pizzuti, L. A. D., \& Cattelam, J. (2013). Parâmetros comportamentais de vacas de descarte em pastagens de milheto ou capim sudão. Ciência Animal Brasileira, 14(3), 323-331. doi: 10.5216/cab. v14i3.23613

Pizzuti, L. A. D., Alves, D. C., Fº, Brondani, I. L., Pacheco, P. S., Freitas, L. S., Segabinazzi, L. R.,... Teixeira, O. S. (2012). Behavior pattern of beef heifers supplemented with different energy sources on oat and ryegrass pasture. Revista Brasileira de Zootecnia, 41(8), 1921-1927. doi: 10.1590/S151635982012000800017
Reis, R. A., Ruggieri, A. C., Oliveira, A. A., Azenha, M. V., \& Casagrande, D. R. (2012). Suplementação como estratégia de produção de carne de qualidade em pastagens tropicais. Revista Brasileira Saúde e Produção Animal, 13(3), 642-655. doi: 10.1590/ S1519-99402012000300005

Rodrigues, L. S., Alves, D. C., Fº, Brondani, I. L., Restle, J., Silva, V. S., Colvero, P. C. P.,... Bona, R. A. (2019). Comportamento ingestivo de novilhas de corte em pastagem de sorgo forrageiro implantada com diferentes arranjos populacionais. Arquivo Brasileiro de Medicina Veterinária e Zootecnia, 71(6), 2025-2033. doi: 10.1590/1678-4162-10026

Sales, M. F. L., Paulino, M. F., Valadares, S. C., F., Figueiredo, D. M., Porto, M. O., \& Detmann, E. (2011). Supplementation levels for growing beef cattle grazing in the dry-rainy transition season. Revista Brasileira de Zootecnia, 40(4), 904-911. doi: 10.1590/S1516-3598201100040 0027

Santana, H. A., Jr., Silva, R. R., Carvalho, G. G. P., Silva, F. F., Barroso, D. S., Pinheiro, A. A.,... Trindade, G., Jr. (2013). Correlação entre desempenho e comportamento ingestivo de novilhas suplementadas a pasto. Semina: Ciências Agrárias, 34(1), 367-376. doi: 10.5433/1679-0359. 2013v34n1p367

Santana, H. A., Jr., Silva, R. R., Carvalho, G. G. P., Silva, F. F., Mendes, F. B. L., Abreu, G., Fº,... Pereira, M. M. (2012). Correlação entre digestibilidade e comportamento ingestivo de novilhas suplementadas a pasto. Archivos de Zootecnia, 61(236), 549-558. doi: 10.4321/S0004-05922012000400007

Scaglia, G., \& Boland, H. T. (2014). The effect of bermudagrass hybrid on forage characteristics, animal performance, and grazing behavior of beef steers. Journal of Animal Science, 92, 1228-1238. doi: $10.2527 /$ jas2013-6959

Sichonany, M. J. O., Rocha, M. R., Pötter, L., Oliveira, A. P. B. B., Ribeiro, L. A., Silva, M. F.,... Salvador, P. R. (2015). Ingestive behavior of heifers in Alexander grass pasture receiving different amounts of oat grain as supplement. Semina: Ciências Agrárias, 36(3), 2763-2774. doi: 10.5433/1679-0359.2015v3 $6 \mathrm{n} 4 \mathrm{p} 2763$

Silva, R. R., Prado, I. N., Carvalho, G. G. P., Silva, F. F., Santana, H. A., Jr., Souza, D. R.,... Paixão, M. L. (2010). Novilhos nelore suplementados em pastagens: consumo, desempenho e digestibilidade. Archivos de Zootecnia, 59(228), 549-560. Recuperado de http:// scielo.isciii.es/ pdf/azoo/v59n228/art8.pdf 
Souza, A. N. M., Rocha, M. G., Pötter, L., Roso, D., Glienke, C. L., \& Oliveira Neto, R. A. (2011). Comportamento ingestivo de novilhas de corte em pastagem de gramíneas anuais de estação quente. Revista Brasileira de Zootecnia, 40(8), 1662-1670. doi: 10.1590/S1516-3598201100 0800006

Stivanin, S. C. B., Rocha, M. G., Potter, L., Hampel, V. S., Oliveira, R. A., \& Bergoli, T. L. (2014). Ingestive behavior of hoggets given different types of supplement on ryegrass pasture. Acta Scientiarum. Animal Sciences, 36(1), 101-107. doi: 10.4025/ actascianimsci.v36i1.21641
Stobbs, T. H. (1973). The effect of plant structure on the intake of tropical pasture. II-Differences in sward, nutritive value and bite size of animals grazing Setaria anceps and Chloysgaiana at various stages of growth. Australian Journal of Agricultural Research, 24(6), 821-829. doi: 10. 1071/AR9730809

Teixeira, F. A., Marques, J. A., Silva, F. F., \& Pires, A. J. V. (2010). Comportamento ingestivo e padrão de deslocamento de bovinos em pastagens tropicais. Archivos de Zootecnia, 59(R), 57-70. doi: 10.21071/ az.v59i232.4907 
